\title{
Vitamin E and Sodium Selenite Against Mercuric Chloride- Induced Lung Toxicity in the Rats
}

\author{
Emine Celikoglu ${ }^{1}$, Ayse Aslanturk ${ }^{2 *}$ and Yusuf Kalender ${ }^{2}$ \\ ${ }^{I}$ Department of Biology, Science Faculty; Anadolu University; Eskisehir - Turkey. ${ }^{2}$ Gazi University - Vocational \\ High School of Health Services; Ankara - Turkey
}

\begin{abstract}
The aim of the present study was to elucidate the possible protective role of vitamin E and / or sodium selenite on mercuric chloride-induced oxidative stress and histopathological changes in the lung tissue of the rats. Adult male albino Wistar rats were exposed to mercuric chloride (1.0 $\mathrm{mg} / \mathrm{kg}$ day) for four weeks. Treatment with mercuric chloride led to oxidative stress by enhancing MDA level and also decreasing superoxide dismutase (SOD), catalase $(C A T)$ glutathione peroxidase (GPx) and glutathione $S$ transferaz (GST) activities. However, mercuric chloride exposure resulted in histopathological changes in the lung tissue in the rats. MDA level and SOD, CAT GPX and GST activities and histopathological changes modulated in concomitantly supplementation of vitamin E (100 mg/kg day) and /or sodium selenite (0.25 $\mathrm{mg} / \mathrm{kg}$ day) to mercuric chloride-treated groups.
\end{abstract}

Key words: Mercuric chloride, Sodium selenite, Vitamin E, Lung toxicity, Oxidative stress, Histopathology

\section{INTRODUCTION}

Mercury is the third most dangerous heavy metal and its toxicity causes serious risks to health through unfavorable pathological and biochemical effects (Othman et al. 2014). Mercury is found extensively in many environmental and certain occupational settings (Bridges et al. 2014). It may cause serious damage in various organs as a result of accidental and / or occupational exposures. Mercuric chloride is one of the most toxic forms of mercury and is primarily nephrotoxic (MoraesSilva 2014). It is well known as hematotoxic (Durak et al. 2010), hepatotoxic (Joshi et al. 2014; Othman et al. 2014), neurotoxic (Moraes-Silva et al. 2014), nephrotoxic (Aslanturk et al. 2014) and genotoxic (Rozgaj et al. 2005) and exerts negative effects on the reproductive system in male rat (Kalender et al. 2013).
Mercury exposure encourages formation of reactive oxygen species (ROS) (Perottoni et al. 2004). Excessive production of ROS due to mercuric chloride treatment causes oxidative stress (Haibo et al. 2011). Oxidative stress is defined as an imbalance between the production of ROS and their elimination by antioxidant systems. This imbalance causes severe damage of important biomolecules and organs (Duracková 2010). Many studies have focused on the possible protective effects of various antioxidant agents on oxidative damage caused by heavy metals (Oguzturk et al. 2012; Joshi et al. 2014; GarcíaNiño and Pedraza Chaverri 2014; Othman et al. 2014). Selenium (Se), an essential trace element, plays key regulator role in a variety of biological pathways, including particularly in the oxidative stress defence system (Ahsan et al. 2014). Vitamin $\mathrm{E}$ is reported as the most effective fat soluble antioxidant and is known to have been

*Author for correspondence: ayseogutcu@gmail.com 
demonstrated helpful in some disease processes. It protects the body's biological systems due to preventions of lipid peroxidation by scavenging free radicals ability in lipoprotein membranes (Al Attar 2011). Several studies have reported that vitamin $\mathrm{E}$ and selenium play beneficial role against adverse effects of toxic compounds in various organ (Kalender et al. 2013; Dezfouli et al. 2014; Ranjan et al. 2014; Hassani et al. 2015). However, vitamin $\mathrm{E}$ and selenium are not only effective against oxidative damage alone, but also have a synergistic effect when they are used together (Schwenke and Behr 1998). Therefore, this study was designed to evaluate the potential protective roles of the two antioxidants, vitamin $\mathrm{E}$ and sodium selenite, against oxidative damage and histopathological changes in the lung tissue by mercuric chloride-induced in male rats.

\section{MATERIAL AND METHODS}

\section{Chemicals}

Mercuric chloride $\left(\mathrm{HgCl}_{2}, 99 \%\right.$ purity) and sodium selenite $\left(\mathrm{Na}_{2} \mathrm{SeO}_{3}, 99 \%\right.$ purity) were purchased from Sigma Aldrich (Germany). Vitamin E (DL- $\alpha$-tocopherol acetate; $500 \mathrm{mg}$ DL$\alpha$-tocopherol acetate per $\mathrm{ml}$ ) was obtained from Merck (Germany).

\section{Experimental design}

Forty-eight male Wistar albino rats, weighing between 300 and $320 \mathrm{~g}$, were obtained from the Gazi University Laboratory Animals Growing and Experimental Research Center. Rats were maintained at the controlled temperature $(22 \pm 3)$ and $12 \mathrm{~h}$ alternate light and dark conditions, fed with the standard diet and water ad libitum and acclimatized for 10 days to the laboratory conditions. All the experimental procedures were approved by the Gazi University Committee on the Ethics of Animal Experimentation (G.U. ET 10.026).

Experimental animals were randomly divided into eight groups, each consisting of six rats. Group 1 rats received $1.0 \mathrm{~mL} / \mathrm{kg}$ bw corn oil per day, per oral (p.o.); group 2, rats were treated with vitamin E p.o. (100 mg/kg bw per day in corn oil); group 3 rats received sodium selenite p.o. $(0.25 \mathrm{mg} / \mathrm{kg}$ bw per day in distilled water); group 4 animals received vitamin $\mathrm{E}+$ sodium selenite p.o. (100 $\mathrm{mg} / \mathrm{kg} \mathrm{bw}+0.25 \mathrm{mg} / \mathrm{kg}$ bw per day, respectively); group 5 rats were treated with mercuric chloride p.o. (1.0 $\mathrm{mg} / \mathrm{kg}$ bw per day in distilled water); in group 6 animals received both vitamin $\mathrm{E}$ and mercuric chloride p.o. $(100 \mathrm{mg} / \mathrm{kg}$ bw $+1.0 \mathrm{mg} / \mathrm{kg}$ bw per day, respectively); in group 7 rats received sodium selenite + mercuric chloride p.o. $(0.25$ $\mathrm{mg} / \mathrm{kg}$ bw $+1.0 \mathrm{mg} / \mathrm{kg}$ bw per day, respectively); and, group 8 rats were treated with vitamin $\mathrm{E}+$ sodium selenite + mercuric chloride p.o. (100 $\mathrm{mg} / \mathrm{kg}$ bw $+0.25 \mathrm{mg} / \mathrm{kg}+1.0 \mathrm{mg} / \mathrm{kg}$ bw per day, respectively). These compounds were administered to the adult rats for four weeks.

\section{Assessment of Oxidative Stress Biomarkers}

Malondialdehyde (MDA) level was determined using the thiobarbituric acid (TBA) test according to a previously described method by Ohkawa et al. (1979). Absorbance was measured at $532 \mathrm{~nm}$ to evaluate the MDA content. The MDA content was expressed as $\mathrm{nmol} / \mathrm{mg}$ protein.

Superoxide dismutase (SOD) activity was performed according to Marklund and Marklund (1974). SOD activity was expressed as U/mg protein. Catalase (CAT) activity was measured according to the method of Aebi (1984). The enzyme activity was expressed as $\mathrm{mmol} / \mathrm{mg}$ protein. Glutathione peroxidase (GPx) activity was estimated using $\mathrm{H}_{2} \mathrm{O}_{2}$ as substrate according to Paglia and Valentine (1967). GPx activity was expressed as $\mu \mathrm{mol} / \mathrm{mg}$ protein. Glutathione $\mathrm{S}$ transferaz (GST) activity was performed by measuring the formation of GSH (glutathione) and the 1-chloro-2,4-dinitrobenzene (CDNB) conjugate according to Habig et al. (1974). The enzyme activity was expressed as $\mathrm{nmol} / \mathrm{mg}$ protein. Protein content of the lung homogenates was determined according to the method of Lowry et al. (1951) using bovine serum albumin (BSA) as standard.

\section{Histological Assay}

The lung tissues were collected, and fixed in Bouin solution, dehydrated using a graded ethanol series and embedded in paraffin and then sectioned at 6-7 $\mu \mathrm{m}$ thickness. Sections were stained with hematoxylin and eosin. The tissue sections were evaluated under light microscope (Olympus BX51, Tokyo, Japan) and photographed with a digital camera (Olympus E-330, Olympus Optical Co. Ltd., Japan).

\section{Statistical Analysis}

A computer program SPSS 11.0 was used for the statistical analysis. Differences between the group 
means were analyzed using one-way analysis of variance (ANOVA), followed by Tukey's procedure for multiple comparisons. All data were presented as means \pm SD. Results were considered statistically significant when P-value was $<0.05$.

\section{RESULTS}

\section{Oxidative Stress Biomarkers}

There was no significant difference in the MDA level and SOD, CAT, GPx and GST activities in vitamin E-treated group, sodium selenite-treated group and vitamin E plus sodium selenite-treated group compared to control group. A significant increase in the level of MDA was observed in mercuric chloride-treated group, vitamin E plus mercuric chloride-treated group, sodium selenite plus mercuric chloride-treated group, vitamin $\mathrm{E}$ plus sodium selenite plus mercuric chloride- treated group rats as compared with the control group rat. However, decreases were recorded in the SOD, CAT, GPx and GST activities of the mercuric chloride-, vitamin E plus mercuric chloride-, sodium selenite plus mercuric chlorideand vitamin E plus sodium selenite plus mercuric chloride-treated groups relative to that of the control group.

A significant decline was observed in the MDA level of vitamin E plus mercuric chloride-, sodium selenite plus mercuric chloride-, vitamin E plus sodium selenite plus mercuric chloride-treated group rats when compared with that in the mercuric chloride-treated group rat. However, the SOD, CAT, GPx and GST activities of the vitamin E plus mercuric chloride-, sodium selenite plus mercuric chloride-, vitamin E plus sodium selenite plus mercuric chloride-treated group rats were relatively higher compared to the mercuric chloride-treated group rat $(p<0.05$, Table 1).

Table 1 - Effects of exposure to mercuric chloride on the antioxidant enzyme activities and MDA level in lung tissue of rats.

\begin{tabular}{|c|c|c|c|c|c|}
\hline Groups & $\begin{array}{c}\text { MDA } \\
\text { (nmol/mg protein) }\end{array}$ & $\begin{array}{c}\text { SOD } \\
\text { (U/mg protein) }\end{array}$ & $\begin{array}{c}\text { CAT } \\
(\mathbf{m m o l} / \mathbf{m g} \text { protein) }\end{array}$ & $\begin{array}{c}\text { GPx } \\
(\mu \mathrm{mol} / \mathbf{m g} \text { protein })\end{array}$ & $\begin{array}{c}\text { GST } \\
\text { (nmol/mg protein) }\end{array}$ \\
\hline Control & $0.024 \pm 0.00041$ & $5.465 \pm 0.24$ & $3.311 \pm 0.17$ & $4.546 \pm 0.12$ & $0.041 \pm 0.001$ \\
\hline Vitamin E & $0.024 \pm 0.001$ & $5.365 \pm 0.18$ & $3.316 \pm 0.15$ & $4.416 \pm 0.22$ & $0.042 \pm 0.001$ \\
\hline Sodium selenite & $0.024 \pm 0.0006$ & $5.485 \pm 0.17$ & $3.331 \pm 0.14$ & $4.408 \pm 0.18$ & $0.044 \pm 0.001$ \\
\hline $\begin{array}{l}\text { Vitamin E } \\
\text { +Sodium selenite }\end{array}$ & $0.024 \pm 0.0007$ & $5.406 \pm 0.12$ & $3.283 \pm 0.18$ & $4.360 \pm 0.23$ & $0.044 \pm 0.001$ \\
\hline Mercuric chloride & $0.031 \pm 0.0014^{\mathrm{a}, \mathrm{b}, \mathrm{c}, \mathrm{d}}$ & $3.243 \pm 0.15^{\mathrm{a}, \mathrm{b}, \mathrm{c}, \mathrm{d}}$ & $1.000 \pm 0.08^{\mathrm{a}, \mathrm{b}, \mathrm{c}, \mathrm{d}}$ & $2.251 \pm 0.15^{\mathrm{a}, \mathrm{b}, \mathrm{c}, \mathrm{d}}$ & $0.032 \pm 0.001^{\mathrm{a}, \mathrm{b}, \mathrm{c}, \mathrm{d}}$ \\
\hline $\begin{array}{l}\text { VitaminE } \\
\text { +Mercuric chloride }\end{array}$ & $0.026 \pm 0.0006^{\mathrm{a}, \mathrm{b}, \mathrm{c}, \mathrm{d}, \mathrm{e}}$ & $4.375 \pm 0.18^{\mathrm{a}, \mathrm{b}, \mathrm{c}, \mathrm{d}, \mathrm{e}}$ & $2.040 \pm 0.12^{\mathrm{a}, \mathrm{b}, \mathrm{c}, \mathrm{d}, \mathrm{e}}$ & $3.478 \pm 0.15^{\mathrm{a}, \mathrm{b}, \mathrm{c}, \mathrm{d}, \mathrm{e}}$ & $0.037 \pm 0.001^{\mathrm{a}, \mathrm{b}, \mathrm{c}, \mathrm{d}, \mathrm{e}}$ \\
\hline $\begin{array}{l}\text { Sodium selenite } \\
+ \text { Mercuric chloride } \\
\text { Vitamin E }\end{array}$ & $0.027 \pm 0.0011^{\mathrm{a}, \mathrm{b}, \mathrm{c}, \mathrm{d}, \mathrm{e}}$ & $4.54 \pm 0.14^{\mathrm{a}, \mathrm{b}, \mathrm{c}, \mathrm{d}, \mathrm{e}}$ & $1.886 \pm 0.04^{\mathrm{a}, \mathrm{b}, \mathrm{c}, \mathrm{d}, \mathrm{e}}$ & $3.345 \pm 0.18^{\mathrm{a}, \mathrm{b}, \mathrm{c}, \mathrm{d}, \mathrm{e}}$ & $0.038 \pm 0.001^{\mathrm{a}, \mathrm{b}, \mathrm{c}, \mathrm{d}, \mathrm{e}}$ \\
\hline $\begin{array}{l}+ \text { Sodium selenite } \\
+\mathrm{HgCl}_{2}\end{array}$ & $0.026 \pm 0.0009^{\mathrm{a}, \mathrm{b}, \mathrm{c}, \mathrm{d}, \mathrm{e}}$ & $4.23 \pm 0.14^{\mathrm{a}, \mathrm{b}, \mathrm{c}, \mathrm{d}, \mathrm{e}}$ & $2.038 \pm 0.13^{\mathrm{a}, \mathrm{b}, \mathrm{c}, \mathrm{d}, \mathrm{e}}$ & $3.521 \pm 0.16^{\mathrm{a}, \mathrm{b}, \mathrm{c}, \mathrm{d}, \mathrm{e}}$ & $0.037 \pm 0.001^{\mathrm{a}, \mathrm{b}, \mathrm{c}, \mathrm{d}, \mathrm{e}}$ \\
\hline
\end{tabular}

Values are mean \pm Standard Deviation (SD) of six rats in each group. Significance at $\mathrm{P}<0.05$.

${ }^{a}$ Comparison of control and other groups. ${ }^{b}$ Comparison of vitamin E -treated group and other groups. ${ }^{c}$ Comparison of sodium selenite -treated group and other groups. ${ }^{\mathrm{d}}$ Comparison of vitamin E plus sodium selenite -treated group and other groups.

${ }^{\mathrm{e}}$ Comparison of mercuric chloride -treated group and other groups.

\section{Histopathological findings}

The samples of the lung tissues from all the groups were processed for histopathological assessment, which showed the lung in the control group, vitamin E-treated group, sodium selenite-treated group, and vitamin E plus sodium selenite-treated group animals as normal (Fig. 1A). Edema, hemorrhage, interalveolar septa thickening, infiltration of inflammatory cells, fibrosis were observed in the lung tissues of mercuric chloride- treated rats (Fig. 1B-C). However, when mercuric chloride was given vitamin $\mathrm{E}$ or sodium selenite infiltration of inflammatory cells, interalveolar septa thickening and degeneration of terminal bronchioles epithelium were observed (Fig. 1D-E) respectively. In vitamin $\mathrm{E}$ plus sodium selenite plus mercuric chloride-treated group, more moderate interalveolar septa thickening was observed compared to the mercuric chloride treated group (Fig. 1F). 

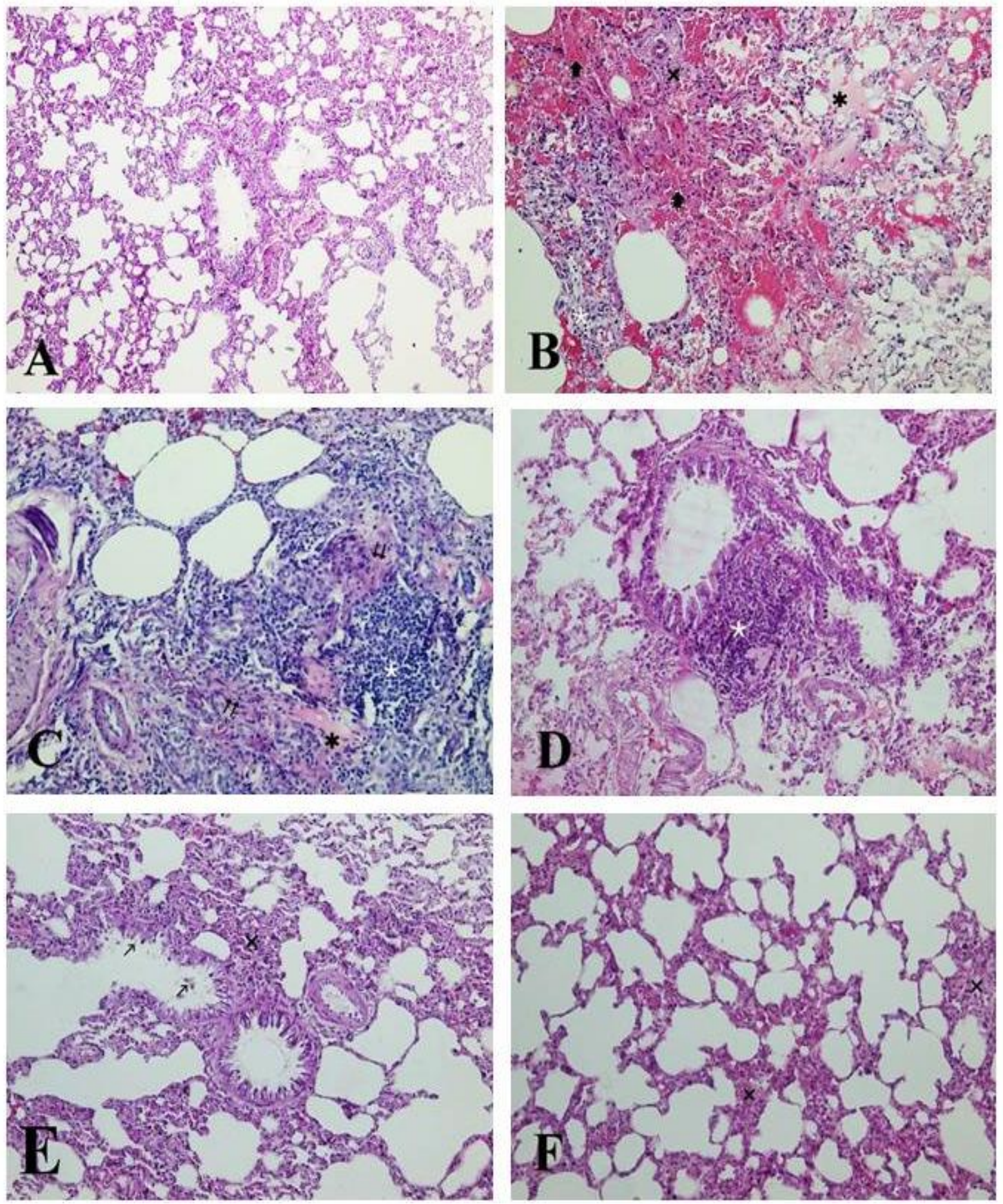

Figure 1 - (A) Lung section of control rats, $\times 200$. (B-C) Lung sections of mercuric chloride-treated rats showing edema $(\boldsymbol{*})$, hemorrhage $(\boldsymbol{\rightarrow})$, interalveolar septa thickening $(\mathbf{X})$, infiltration of inflammatory cells $(\star)$, fibrosis $(\rightrightarrows), \times 200$. (D-E respectively) Lung section of vitamin $\mathrm{E}+$ mercuric chloride - and sodium selenite + mercuric chloride -treated rats showing infiltration of inflammatory cells $(\star)$, interalveolar septa thickening $(\mathbf{X})$ and degeneration of bronchioles epithelium $(\rightarrow), \times 200$. (F) Lung section of vitamin E + sodium selenite + mercuric chloride -treated rats showing more moderate interalveolar septa thickening $(\mathbf{X})$, $\times 200$. 


\section{DISCUSSION}

Mercury is one of the most widespread heavy metals, which are used in agriculture, pharmacology and industry (Agha et al. 2014). Heavy metals enter into the human body through the lungs, stomach or skin and their presence may cause serious toxicity (Jarup 2003; Alissa and Ferns 2011). The presence of mercuric chloride in the biological tissues leads to many adverse alterations that affect the health of the organism (Othman et al. 2014). Heavy metals are persistent and widespread pollutants that affect the structure and function of several organs by generating oxidative stress (García-Niño and Pedraza Chaverri 2014). Mercuric compounds enhance generation of many reactive oxygen species, such as superoxide and hydrogen peroxides, which cause lipid peroxidation, resulting in oxidative tissue damage. Oxidative stress refers to extreme generation of reactive oxygen species (Haibo et al. 2011). Malondialdehyde is a stable metabolite of lipid peroxidation induced by the oxidative stress in the cells (Boroushaki et al. 2014). MDA is one of the most potential biomarker of the degree of lipid peroxidation (Sener et al. 2007).

The present study demonstrated that mercuric chloride resulted a significant increase in the MDA level in the lung tissue, indicative of the generation of lipid peroxides. Previous studies have shown that heavy metals induced elevated MDA level in the lung tissue (Sener et al. 2003; Sener et al. 2007; Karaca and Eraslan 2013). Enhanced level of lipid peroxidation was also reported in mercuric chloride toxicity (Kalender et al. 2013; Aslanturk et al. 2014; Othman et al. 2014; Agha et al. 2014). The escalation of lung MDA level may be due to the adverse effect of mercuric chloride on cell membrane. However, the enhanced MDA level might be conclusion of increased formation of free radicals. Mercury chloride-induced elevated MDA level could be used as a marker of mercuric chloride damage (Aslanturk et al. 2014).

The endogenous antioxidant enzymes such as SOD, CAT, GPx and GST present the first line of cellular antioxidative defense against free-radical damage (Hassani et al. 2015). Inhibition in the activities of antioxidant enzymes like SOD, CAT, GPx and GST in various rat tissues mercuric chloride-treated was revealed in previously studies (Gado and Aldahmash 2103; Kalender et al. 2013). Results showed that there was a statistically significant decrease in SOD, CAT, GPx and GST activities in the lung tissues of mercury chloride treated rats. These enzymes convert free radicals or reactive oxygen intermediates to non-radical products (Kanter et al. 2013). Superoxide radicals are converted to hydrogen peroxide by SOD while CAT converts hydrogen peroxide into water as a defence against the oxidative tissue damage (ElDemerdash 2011). CAT protects the cells from hydrogen peroxide generated within them and plays an important role in the acquisition of tolerance to oxidative stress in the adaptive response of cells (Mates et al. 1999)

In this study, depletion of SOD and CAT activities could be due to the increased production of reactive oxygen species as evident from the increased LPO levels due to mercuric chloride treatment. However, some studies have reported that superoxide radicals could also inhibit CAT activity and the elevated hydrogen peroxide level resulting from CAT inhibition could eventually inhibit SOD activity (Zama et al. 2007). Thus, in this study, the increased MDA level could be due to decreased activities of SOD and CAT, the free radical scavenging enzymes.

GPx is one of the main enzymes that scavenges harmful reactive oxygen species and presents both in cytosol and mitochondrial matrix. The major function of this enzyme is the removal and detoxification of hydrogen peroxide and lipid hydroperoxides in the presence of oxidized GSH (Pappas et al. 2008; Kanbur et al. 2009; Vijayaprakash et al. 2013). In the present study, mercury chloride treatmentresulted in decrease of GPx activity in the rats. Mercuric chloride may block the GPx activity by disrupting the functional groups (Hussain et al. 1997). However, the inhibition of the CAT and GPx activities may be due to as a defence response used against excessive hydrogen peroxide produced by the mercury chloride (Bharathi et al. 2012). Also, the inhibition of GPx activity might be due to inactivation of the hydrogen peroxide scavenging CAT enzyme.

Glutathione S-transferases (GSTs) are a group of intracellular enzymes with the major function in the detoxification procedures by catalyzing the conjugation of glutathione with some endogenous toxic metabolites and many environmental pollutants (Nimmo 1987). Elevated oxidative stress and reduced antioxidant enzyme activities which are the main causes of lung toxicity of mercuric chloride (Boroushaki et al. 2014). 
Antioxidant therapy may be regarded as a good strategy to mitigate the oxidative stress. Vitamin E may prevent adverse effects of reactive oxygen radical reactions. The molecular and cellular protecting mechanism of vitamin $\mathrm{E}$ includes either scavenging of free-radicals or protecting cellular structure such as membrane and lipid domain and regulating specific enzymes. It may also inhibit the generation of lipid peroxidation by blocking the propagation of chain reaction of lipid peroxidation in cellular membranes (Hassani et al. 2015). Several studies have reported that vitamin E can protect heavy metal-induced tissue and organ damage (Rao and Sharma 2001; El-Demerdash 2004; Agarwal et al. 2010; Al Attar 2011). Selenium (Se) is an integral component of the cellular antioxidant defense system. Sodium selenite, a common dietary form of selenium, is regarded as essential in the all mammalian species nutrition. Selenium has the ability to reduce the toxicity of several xenobiotics, including heavy metals (Agha et al. 2014). Many studies have reported that, when selenium in the form of sodium selenite is given in combination with mercury administration, it significantly alleviates the mercury-induced toxic effects (Kalender et al. 2013; Agha et al. 2014). Selenium possesses an affinity for mercury higher than that of sulfhydryl compounds and the protection offered by sodium selenite in mercury intoxication has been based on to the formation of $\mathrm{Hg}-\mathrm{Se}-\mathrm{S}$ complex to form a non-toxic complex (Perottoni et al. 2004). In the present study, treatment of vitamin $\mathrm{E}$ and / or sodium selenite to the mercuric chloride-treated rats enhanced SOD, CAT, GPx and GST activities and reduced malondialdehyde level in the lung tissue. The declined MDA level along with elevated antioxidant enzyme activities in antioxidant groups reflected the decreased oxidative stress in the lung tissue. This protective effect of vitamin E and / or sodium selenite could be due to the major role of sodium selenite and vitamin $\mathrm{E}$ in limiting lipid peroxidation and in preserving the wholeness and functioning of the tissues and cells (Ognjanovic et al. 2008). This effect could also explain the mechanism of protection that includes the capability of Se to alter the distribution of mercury in tissues and induces the formation of the $\mathrm{Hg}$-Se non-toxic complex and disrupted absorption of mercury in the presence of vitamin $\mathrm{E}$ in the gastrointestinal tract. Earlier studies have reported that selenium and / or vitamin $\mathrm{E}$ protect against mercury toxicity
(Beyrouty and Chan 2006; Kalender et al. 2013; Deepmala et al. 2013; Joshi et al. 2014). There are other studies, which reported that heavy metals caused histopathological alterations in the lung tissue (Das et al. 1997; Yoshida et al. 1999; Onarlioglu et al. 1999; Kaczynska et al. 2011; El Bamby et al. 2012; Blum et al. 2014). In the present study, oral exposure to mercuric chloride caused histopathological changes like edema, hemorrhage, infiltration of inflammatory cells, interalveolar septa thickening, degeneration in alveoli and bronchioles, fibrosis were observed in the lung tissue. These changes might be due to the excessive formation of reactive oxygen species induced by mercuric chloride. The oxygen radicals attack the cell membrane and lead to destabilization and disintegration of cell membrane as a result of lipid peroxidation (Stajn et al. 1997). The reason of histopathological alterations may be elevated lipid peroxidation formed by mercuric chloride. These histopathological changes were more mild in the vitamin $\mathrm{E}$ and / or sodium selenite plus mercuric chloride-treated group. The light microscopic findings harmonized with these findings of biochemical examinations. Consequently, oral administration of vitamin $\mathrm{E}$ and /or sodium selenite could alleviate the mercuric chlorideinduced lung toxicity.

\section{CONCLUSIONS}

In conclusion, results from the present study suggested mercuric chloride treatment resulted lipid peroxidation, alterations of enzymatic antioxidant defense system and histolopathological changes in the lung tissue of male rats. The administration of vitamin $\mathrm{E}$ and/or sodium selenite proved to be beneficial in alleviating the mercuric chloride-induced lung toxicity.

\section{ACKNOWLEDGMENT}

The authors are thankful to the Gazi University Research Fund for support.

\section{REFERENCES}

Aebi H. Catalase in vitro. Method Enzymol. 1984; 105: 121-126. 
Agarwal R, Goel SK, Chandra R, Behari JR. Role of vitamin $E$ in preventing acute mercury toxicity in rat. Environ Toxicol Phar. 2010; 29: 70-78.

Agha FE, Youness ER, Selim MMH, Ahmed HH. Nephroprotective potential of selenium and taurine against mercuric chloride induced nephropathy in rats. Ren Fail. 2014; 36: 704-716.

Ahsan U, Kamran Z, Raza I, Ahmad S, Babar W, Riaz $\mathrm{MH}$, et al. Role of selenium in male reproduction-A review. Animal Reprod Sci. 2014; 146: 55-62.

Al-Attar AM. Antioxidant effect of vitamin E treatment on some heavy metals-induced renal and testicular injuries in male mice. Saudi J Biol Sci. 2011; 18: 6372.

Alissa E, Ferns G. Heavy metal poisoning and cardiovascular disease. J Toxicol. 2011: 1-21.

Aslanturk A, Uzunhisarcikli M, Kalender S, Demir F. Sodium selenite and vitamin $\mathrm{E}$ in preventing mercuric chloride induced renal toxicity in rats. Food Chem Toxicol. 2014; 70: 185-190.

Beyrouty P, Chan HM. Co-consumption of selenium and vitamin $\mathrm{E}$ altered the reproductive and developmental toxicity of methylmercury in rats. Neurotox Teratol. 2006; 28: 49-58.

Bharathi E, Jagadeesan G, Manivasagam T. Influence of s-allyl cysteine against mercuric chloride induced nephrotoxicity in albino rats. J Chem Phar Res. 2012; 4: 1470-1474.

Blum JL, Rosenblum LK, Grunig G, Beasley MB, Xiong JQ, Zelikoff JT. Short-term inhalation of cadmium oxide nanoparticles alters pulmonary dynamics associated with lung injury, inflammation, and repair in a mouse model. Inhal Toxicol. 2014; 26: 48-58.

Boroushaki MT, Mollazadeh H, Rajabian A, Dolati K, Hoseini A, Pasebania M, et al. Protective effects of crocin against cisplatin-induced acute renal failure and oxidative stress in rats. Ren Fail. 2014; 36(10): 1581-1586.

Bridges CC, Joshee L, Zalups RK. Aging and the disposition and toxicity of mercury in rats. Exp Gerontol. 2014; 53: 31-39.

Das RM, Ahmed MK, Oulton MR, Mantsch HH, Tsubai T, Scott JE. Methylmercury-induced alterations in lung and pulmonary surfactant properties of adult mice. Chem Phys Lipids. 1997; 89:107-117.

Deepmala J, Deepak M, Srivastav S, Sangeeta S, Kumar SA, Kumar SS. Protective effect of combined therapy with dithiothreitol, zinc and selenium protects acute mercury induced oxidative injury in rats. $J$ Trace Elem Med Biol. 2013; 27: 249-256.

Dezfouli MGZ, Eisszadeh S, Ali SM, Zade S. Histological and histometrical study of the protective role of $\alpha$-tocopherol against sodium arsenite toxicity in rat ovaries. Microsc Microanal. 2014; 20: 11671179.
Duracková Z. Some current insights into oxidative stress. Physiol Res. 2010; 59: 459-469.

Durak D, Kalender S, Uzun FG, Demir F, Kalender Y. Mercury chloride induced oxidative stress and the protective effect of vitamins $\mathrm{C}$ and $\mathrm{E}$ in human erythrocytes in vitro. AJB. 2010; 9: 488-495.

El-Bamby MM, Abu-Sheir WA, Abou-Amer WL, Marzouk EMA. Effect of Aliminum, cadmium and lead on rat lung: Protective of selenium. Az J Pharm Sci. 2012; 45: 121-136.

El-Demerdash FM. Antioxidant effect of vitamin E and selenium on lipit peroxidation, enzyme activities and biochemical parameters in rats exposed to aluminium. J Trace Elem Med Bio. 2004; 18: 113-121.

El-Demerdash FM. Oxidative stress and hepatotoxicity induced by synthetic pyrethroids organophosphate insecticides mixture in rat. J Environ Sci Health. 2011; 29: 145-158.

Gado AM, Aldahmash BA. Antioxidant effect of Arabic gum against mercuric chloride-induced nephrotoxicity. Drug Des Dev Ther. 2013; 7: 12451252.

García-Niño W R, Pedraza-Chaverri J. Protective effect of curcumin against heavy metals-induced liver damage. Food Chem Toxicol. 2014; 69: 182-201.

Habig WH, Pabst MJ, Jakoby WB. Glutathione-Stransferases: the first enzymatic step in mercapturic acid formation. J Biol Chem. 1974; 249: 7130-7139.

Haibo Y, Zhaofa X, Wei L, Yu D, Bin X. The protective role of procyanidins and lycopene against mercuric chloride renal damage in rats. Biomed Environ Sci. 2011; 24: 550-559.

Hussain S, Rodgers D, Duhart HA, Ali SF. Mercuric chloride-induced reactive oxygen species and its effect on antioxidant enzymes in different regions of rat brain. J Environ Sci Health B. 1997; 32: 395-409.

Hassani S, Sepand MR, Jafari A, Jaafari J, Rezaee R, Zeinali $\mathrm{M}$, et al. Protective effects of curcumin and vitamin $\mathrm{E}$ against chlorpyrifos-induced lung oxidative damage. Hum Exp Toxicol. 2015; 34 (6): 668-676.

Jarup L. Hazards of heavy metal contamination. $\mathrm{Br}$ Med Bull. 2003; 68: 167-182.

Joshi D, Mittal DK, Shukla S, Srivastav AK, Srivastav SK. N-acetyl cysteine and selenium protects mercuric chloride-induced oxidative stress and antioxidant defense system in liver and kidney of rats: A histopathological approach. Trace Elem Med Biol. 2014; 28: 218-226.

Kaczynska K, Walski M, Szereda-Przestaszewska M. Ultrastructural changes in lung tissue after acute lead intoxication in the rat. J Electron Microsc. 2011; 60: 289-294.

Kalender S, Uzun FG, Demir F, Uzunhisarcikli M, Aslanturk A. Mercuric chloride-induced testicular toxicity in rats and the protective role of sodium selenite and vitamin E. Food Chem Toxicol. 2013; 55: 456-462. 
Kanbur M, Eraslan G, Silici S. Antioxidant effect of propolis against exposure to propetamphos in rats. Ecotoxicol Environ Saf. 2009; 72: 909-915.

Kanter M, Aktas C, Erboga M. Curcumin attenuates testicular damage, apoptotic germ cell death, and oxidative stress in streptozotocin-induced diabetic rats. Mol Nutr Food Res. 2013; 57: 1578-1585.

Karaca S, Eraslan G. The effects of flaxseed oil on cadmium-induced oxidative stress in rats. Biol Trace Elem Res. 2013; 155: 423-430.

Lowry OH, Rosebrough NJ, Farr AL, Randall RJ. Protein measurement with the Folin phenol reagent. $J$ Biol Chem. 1951; 19: 265.

Marklund S, Marklund G. Involvement of the superoxide anion radical in the autoxidation of pyrogallol and a convenient assay for superoxide dismutase. EJB. 1974; 47: 469-474.

Mates JM, Cristina PG, Ignacio NC. Antioxidant enzymes and human diseases. Clin Biochem. 1999; 32: 595-603.

Moraes-Silva L, Siqueira LF, Oliveira VA, Oliveira CS, Ineu RP, Pedroso TF, et al. Preventive effect of $\mathrm{CuCl}_{2}$ on behavioral alterations and mercury accumulation in central nervous system induced by $\mathrm{HgCl}_{2}$ in newborn rats. $J$ Biochem Toxicol. 2014; 28: 328-335.

Nimmo IA. The glutathione S-transferase of fish. Fish Physiol Biochem 1987; 3: 163-172.

Ognjanovic BI, Markovic SD, Pavlovic SZ, Zikic RV, Stajn AS, Saicic ZS. Effect of chronic cadmium exposure on antioxidant defence system in some tissues of rats: protective effect of selenium. Physiol Res. 2008; 57: 403-411.

Oguzturk H, Ciftci O, Aydin M, Timurkaan N, Beytur A, Yilmaz F. Ameliorative effects of curcumin against acute cadmium toxicity on male reproductive system in rats. Andrologia. 2012; 44: 243-249.

Ohkawa H, Ohishi N, Yagi K. Assay of lipid peroxidation in animal tissues by thiobarbituric acid reaction. Anal Biochem. 1979; 95: 351-358.

Onarlioglu B, Onarlioglu T, Erdal S. The effect of lead inhalation on rat lung morphology. Tr J Med Sci. 1999; 29: 617-622.

Othman MS, Safwat G, Aboulkhair M, Abdel Moneim AE. The potential effect of berberine in mercuryinduced hepatorenal toxicity in albino rats oxygen species and its effect on antioxidant enzymes in different regions of rat brain. J Environ Sci Health. 2014; 32: 395-409.

Paglia DE, Valentine WN. Studies on the quantitative and qualitative characterization of erythrocytes glutathione peroxidase. J Lab Clin Med. 1967; 70: 158-165.
Pappas AC, Zoidis E, Surai PF Zervas G. Selenoproteins and maternal nutrition. Comp Biochem Physiol B. 2008; 151: 361-372.

Perottoni J, Lobato LP, Silveira A, Rocha JB, Emanuelli T. Effects of mercury and selenite on daminolevulinate dehydratase activity and on selected oxidative stress parameters in rats. Environ Res. 2004; 95: 166-173.

Ranjan B, Daundkar PS, Rampal S. Ameliorative effect of selenium on carbendazim induced oral sub-chronic testicular toxicity in bucks. Small Ruminant Res. 2014; 119: 107-113.

Rao MV, Sharma PSN. Protective effect of vitamin E against mercuric chloride reproductive toxicity in male mice. Reprod Toxicol. 2001; 15: 705-712.

Rozgaj R, Kasuba V, Blanus M. Mercury chloride genotoxicity in rats following oral exposure, evaluated by comet assay and micronucleus test. Arh Hig Rada Toksikol. 2005; 56: 9-15.

Schwenke DC, Behr SR. Vitamin E combined with selenium inhibits atherosclerosis in hypercholesterolemic rabbits independently of effects on plasma cholesterol concentrations. Circ Res. 1998; 83:366-377.

Sener G, Özer SA, Ayanoglu-Dülger G. Melatonin protects against mercury (II)-induced oxidative tissue damage in rats. Pharmacol Toxicol. 2003; 93: 290296.

Sener G, Sehirli Ö, Tozan A, Velioğlu-Övünç A, Gedik N, Omurtag GZ. Ginkgo biloba extract protects against mercury (II)-induced oxidative tissue damage in rats. Food Chem Toxicol. 2007; 45: 543-550.

Stajn A, Ziki RV, Ognjanovic B, Pavlovic SZ, Kostic MM, Petrovic VM. Effect of cadmium and selenium on the antioxidant defence system in rat kidneys. Comp Biochem Physiol. 1997; 2: 167-172.

Vijayaprakash S, Langeswaran K, Kumar SG, Revathy R, Balasubramanian MP. Nephro-protective significance of kaempferol on mercuric chloride induced toxicity in Wistar albino rats. Biomed Agi Pathol. 2013; 3: 119-124.

Yoshida M, Satoh M, Shimada A, Yasutake A, Sumi Y, Tohyama C. Pulmonary toxicity caused by acute exposure to mercury vapor is enhanced in metallothionein-null mice. Life Sci. 1999; 64: 18611867.

Zama D, Meraihi Z, Tebibel S, Benayssa W, Benayache $\mathrm{F}$, Benayache $\mathrm{S}$, et al. Chlorpyrifos-induced oxidative stress and tissue damage in the liver, kidney, brain and fetus in pregnant rats: The protective role of the butanolic extract of Paronychia argentea L. Indian. $J$ Pharm. 2007; 39: 145-150. 